\title{
Lessons to learn: the role of Aboriginal history in promoting reconciliation in the classroom and beyond
}

\section{Tallulah Thompson}

University of Technology Sydney, Faculty of Arts and Social Sciences, PO Box 123, Ultimo NSW 2017, Australia. tallulah.m.thompson@student.uts.edu.au

DOI: https://doi.org/10.5130/nesais.v4i1.1531

\begin{abstract}
Indigenous perspectives are still not fully included within our collective understanding of Australian history, particularly in the classroom. This essay examines the present state of Aboriginal history in Australian school curriculums, arguing that a comprehensive acknowledgement by all major institutions of the nation's past atrocities is imperative to meaningful progress towards reconciliation.
\end{abstract}

Keywords: Aboriginal history; reconciliation; history wars

Australia's colonial past is fraught with violence, oppression and dispossession. While we cannot change our history, we cannot hide from it either, as the wrongs of our past continue to impact current generations of Indigenous Australians. This essay will analyse the role of Aboriginal history in promoting reconciliation, firstly by considering how Indigenous perspectives are still not fully included within our collective understanding of Australian history, particularly in the classroom. The importance of accepting our history will then be explored in light of the divisive ramifications of student disengagement from the topic. This will transition into a discussion regarding the complexity of teaching Indigenous history when not even the courts can provide meaningful recognition of Aboriginal people. Finally, the current national curriculum and specifically the incorporation of Aboriginal history as a 'cross-curriculum priority' will come under the microscope. It is argued that reconciliation is only truly possible when all Australians and major institutions acknowledge and repair the wrongs of our past to ensure they are not repeated in the future. Yet, the apparent failure to incorporate a true and engaging account of history in school curriculums indicates we still have a long way to go.

For the purposes of this essay, 'reconciliation' refers to the coming together of Indigenous peoples and other Australians. It is recognised as a process involving truth, justice and forgiveness, in which a collective understanding and accepting of our past plays a major role (Korff 2018). Furthermore, the term 'Indigenous peoples' is used to describe both Aboriginal and Torres Strait Islander Australians, 
who form two culturally and historically different groups, but together comprise the Indigenous peoples of this nation.

Australia has a difficult history, but until all Australians can understand and accept our collective past, we cannot hope to make reparations and strengthen our relationship with the traditional owners of this land. Aboriginal people have lived on this continent for roughly 65,000 years (Super Nomads 2015). They are the oldest living culture in the world, consisting of various nations and an array of traditions and language groups. Today, recognition of pre-colonial lore and sacred sites is tokenistic at best and exploitative at worst, found at the forefront of many tourism campaigns (Griffiths et al. 2017). Yet, the question remains: how can we celebrate the ancient beginnings of our nation without first accepting and acknowledging the oppressive nature of the past 200 years? The objective of colonisation in Australia was settlement, with Aboriginal people consequently rendered a primitive group, "a fossilised stage in human evolution" who would eventually die out (Griffiths et. al. 2017; Gillan and Ghosh 2007, p. 165). As Morris (1992, p. 73) notes, much of the knowledge we have about the 'other' was produced as part of colonialism. It is what led to the massacre of Aboriginal peoples in the frontier wars (p. 87), as well as the removal of their children and dispossession of their land (Goodall, 1995, p. 76). Excluding them from history effectively reduced their significance, because like any other nation, Australia is a socially constructed and historically produced concept, defined merely by what people believe it to be. The harrowing experiences of Indigenous Australians at the hand of white Australians did not, and arguably still does not, fit with a "white national imaginary" (Stephenson 2003, p. 21).

'The Great Australian Silence' is how W.E.H Stanner (1974, pp. 24-25) described this exclusion of Aboriginal people from Australia's narrative of nationhood, noting that "what may well have begun as a simple forgetting of other possible views turned under habit and over time into something like a cult of forgetfulness practiced on a national scale." Along with the resistance of Aboriginal activists, Stanner was an important figurehead in inspiring the inclusion of Indigenous voices in Australia's history (Curthoys 2008, p. 235). By the 1980s, the nation seemed to be coming to terms with its past (Manne 2009), but this has not necessarily translated into lasting student engagement with Aboriginal history (Clark 2013, p. 76). Indeed, 'The Great Australian Silence' still rings true today, as in the case of Clark's study of students' experiences with Aboriginal history in schools around Australia. She found students were consistently dismissive of the subject, arguing they had studied it repetitively, despite their understanding being far from comprehensive (Clark 2013, p. 68). Even when students acknowledged the importance of Indigenous history, their experiences had been for the most part repetitive and disengaging (p. 65). This is reflected at a broader societal level, where almost 86 per cent of Australians believe the relationship between Aboriginal and Torres Strait Islander people and other Australians is vital, yet there is limited real interaction between the two groups (Reconciliation Australia 2016, p. 8). Where personal interaction is not possible, there are many ways to bridge the gap between Indigenous and non-Indigenous Australians, and schools have a vital role in facilitating that. The fact that students are disengaged from learning about Aboriginal history is preventing the advancement of reconciliation between Indigenous and non-Indigenous Australians.

Historical acceptance is one of five interrelated dimensions identified to measure the success of reconciliation in Australia, but one that is being let down, particularly in the classroom. Reconciliation Australia was founded in 2001 to promote a more holistic idea of reconciliation that encompasses 
rights and practical actions, and has sparked a national debate on prejudice, discrimination and racism (Reconciliation Australia 2016, p. 6). There are five key dimensions necessary for achieving reconciliation between Indigenous and non-Indigenous Australians: race relations, equality and equity, unity, institutional integrity as well as understanding and accepting the wrongs of our past (p. 7). Notably, progress towards a reconciled nation is only as strong as the least advanced dimension, but there is a clear division between Indigenous people's and other Australians' views on how our past has shaped present oppressive circumstances in Aboriginal communities (p. 7). The State of Reconciliation in Australia report highlights a serious lack of understanding and acceptance by nonIndigenous Australians and a sense of historical injustice among Indigenous peoples (p. 2). Today there is still a gap between Indigenous and non-Indigenous people, with the biggest differences in areas of health, education, income, living standards, life expectancy and experiences of racism (Korff 2018). These complex social problems are symptomatic of intergenerational trauma and historical violence, but there is a continued public perception that Aboriginal people are responsible for their own plight (Reconciliation Australia 2016, pp. 14-15).

In the classroom too, students' negative attitudes towards Aboriginal history are having divisive effects (Clark 2013, p. 69). Clark notes familiarity with content breeds contempt, thus students' reluctance to study this history is somehow legitimised by the excessive repetition and poor subject planning (p. 69). However, the overwhelming dislike for the subject matter is having alienating effects on Indigenous students, who feel as though they cannot, or do not, want to talk about Aboriginal history with their peers (p. 69). Some Aboriginal students even admit they do not think it is particularly important to learn about at all, although the suspicion is they just do not want to be the 'Indigenous spokesperson' for risk of not fitting in (p. 69). However, as Marcia Langton (2013, p. 19) argues, the very fact that Aboriginal history is an isolated subject category, rather than part of Australia's collective history, is driving the colonial commitment to race. Indeed, as seen in Clark's (2013, p. 70) findings, some students still believe learning about such topics as white settler invasion is a 'guilt trip'. This is reminiscent of the term 'black armband', used to describe an exaggeratedly negative view of Australia's colonial beginning, and adopted by prominent conservatives including former Prime Minister John Howard (Taylor 2016). Such comments by students suppress the views and culture of their Aboriginal peers and stunt the formation of positive relationships between them. As such, the classroom could be seen as a microcosm for wider society and unless such attitudes change, reconciliation cannot progress. Indeed, we must change the way we tackle the understanding of our past, not only in schools, but in society more broadly. It has been 27 years since Reconciliation Australia was established, and while there have been minor successes, the fact that even Australian courts cannot recognise Aboriginal people's rights is a cause for concern.

Efforts by the courts to repair past wrongs inflicted on Indigenous peoples have been slow to take place or simply disregarded, thus setting a poor example of reconciliation for wider Australia. Legal justice offers Indigenous peoples a sense of hope that their fraught history can be publicly legitimised and righted. This was the case in 1992 after the success of the Mabo High Court decision, which was the first time the Australian law recognised Indigenous people's continuous connection and therefore entitlement to land (Marchetti \& Ransley 2005, p. 534). The Commonwealth Parliament then passed the Native Title Act (1993), which provides a process of determination for the legal recognition of Aboriginal people's land and water rights, where they have unceasingly maintained a connection to it in accordance with traditional law pre-dating 1788 (NSW Aboriginal Land Council 2017, p. 1). 
Nonetheless, there is a common perception among Indigenous peoples that the injustices they have faced in the past have still not been fully rectified (Reconciliation Australia 2016, p. 15). In the case of native title, for instance, the courts very rarely find in favour of Indigenous claimants. This is partially because racially discriminatory legislation and conduct cannot be used to attract redress of lands dispossessed before 1975, when the Racial Discrimination Act was introduced (Marchetti \& Ransley 2005, p. 542). Rather, claims for native title are based solely on whether the plaintiffs have maintained a continued traditional connection to the land, without considering the destructive impacts of colonisation. This highlights how Indigenous people's claims for native title are assessed through a 'white' viewpoint and have resulted in unjust effects. Even when a judge strives for equality under the law, they are still applying Eurocentric values (Marchetti \& Ransley 2005, p. 533).

While a detailed examination of the unconscious racism impacting the justice system is beyond the scope of this essay, the Yorta Yorta case is an interesting example, as it was rejected by the High Court because the claimants' connection to their land was supposedly "swept away by the tide of history" (Atkinson 2001). Wayne Atkinson (2001, p. 548), Yorta Yorta man and principal claimant on the case, argues the use of European sources in court such as squatters and pastoralists over the array of Indigenous knowledge available is a reversion to colonial practices. Indeed, Indigenous perspectives were never meant to be included in the courts, which to an extent has homogenised the way in which issues pertaining to Aboriginal peoples are dealt with today. To date, only eight native title claims have been successful in NSW and there are 21 applications yet to be determined (NSW Aboriginal Land Council 2017, p. 3). The Yorta Yorta case demonstrates the uncompromising refusal of the state to recognise past wrongs and the need to repair them (Atkinson 2001). Clark (2013, p. 81) states, "The moral questions raised by colonisation, dispossession and even reconciliation aren't easily answered in the courts, let alone the classroom." How can teachers be expected to educate students about the facts of history, if, as in the case of native title, even judges in a court of law continue to act as agents of colonisation by effectively ignoring the Indigenous perspective (Marchetti \& Ransley 2005, pp. 534-535)? In this light, Clark (2013, p. 81), maintains that more support for teachers is required, however, the curriculum today still fails to provide comprehensive detail surrounding Aboriginal history.

While incorporating Aboriginal history as a national 'cross-curriculum priority' appears a step towards a more comprehensive understanding of our past, the lack of direction for teachers proves that yet again, these are merely hollow words. According to the Australian Curriculum, Assessment and Reporting Authority (ACARA n.d), cross-curriculum priorities enrich the curriculum through development of focused content. In theory, such focus areas as Aboriginal and Torres Strait Islander Histories and Cultures are meant to fit naturally within existing learning areas. In doing this, the Australian Curriculum is supposedly working towards two distinct needs: for Indigenous students to have the opportunity to see themselves and their culture reflected in the curriculum, as well as to engage all students in reconciliation, respect and recognition of Indigenous peoples (ACARA n.d). However, in an opinion piece for The Canberra Times, former ACARA chairman Barry McGaw (2014) stated, "There is no requirement in the Australian Curriculum that subjects be taught through the three cross-curriculum priorities." As such, the inclusion of Aboriginal history content is left up to the discretion of individual teachers and whether or not they have the time or are willing to include it (Salter and Maxwell 2015, p. 309). It is as if the appearance of progress is deemed sufficient, but in actual fact, it simply furthers a sense of ambivalence towards what is, or rather is not being done, 
risking the total exclusion of Aboriginal voices. Without necessarily meaning to, the school system is reverting to colonial thinking, wherein the history and culture of the 'other' is expelled to its "rightful place" (Salter and Maxwell 2015, p. 309).

Such attitudes fuel the vague and repetitive approach to teaching Aboriginal history, which is turning students off the subject altogether and oppressing Indigenous students as a result. It also fails to address the calls by students who participated in Clark's (2013, pp. 86-87) study, who desire more comprehensive discussions that challenge stereotypes and engage them. Heather Goodall (2002, pp. 11-12) argues there are significant differences in how Indigenous and non-Indigenous Australians understand how the sharing of such history should be implemented. Most importantly, all Australians, starting with those in school, should understand that histories are not a collection of facts, but rather processes of generating narratives which are "always unfinished and always contingent on the teller, their purpose, the context and the audience to whom they speak" (Goodall 2002, p. 12). In addition, while this idea of sharing histories is a key goal of reconciliation, non-Indigenous Australians must respect the fear among Aboriginal communities of giving up custodianship of their stories, especially when bearing in mind the current lack of reparations made to them (p. 11). Clark (2013, p. 88) acknowledges that designing a curriculum is difficult, but says teaching it is even harder. Greater support therefore needs to be provided for those delivering the content in the classroom. Until this is addressed, Aboriginal history will remain marginalised, reconciliation will be even further out of reach, and it will once again be Indigenous people who pay the ultimate price.

In light of the state of reconciliation and lack of meaningful mechanisms for change outlined in this essay, it appears Australia is far from achieving stronger and more trusting relationships between its Indigenous and non-Indigenous peoples. It is clear we must do better at preparing active and informed citizens of the future who understand and acknowledge the value of Indigenous cultures and possess skills to contribute to and benefit from reconciliation. The repercussions of failing to understand and acknowledge our past are dire, but we as a nation can learn from our mistakes. Perhaps, then, we will have a real chance of achieving reconciliation with the traditional owners of this land. For, as $20^{\text {th }}$ century American thinker George Santayana (1905, p. 172) wrote, "Those who cannot remember the past are condemned to repeat it."

\section{References}

Atkinson, W. 2001, 'Not One Iota' of Land Justice: Reflections on the Yorta Yorta Native Title Claim 1994 - 2001', Indigenous Law Bulletin, Vol.5, No.6.

Australian Curriculum, Assessment and Reporting Authority n.d, 'Aboriginal and Torres Strait Islander Histories and Cultures', viewed 3 June 2018, <https://www.australiancurriculum.edu.au/f-10curriculum/cross-curriculum-priorities/aboriginal-and-torres-strait-islander-histories-and-cultures/>.

Clark, A. 2008, History's Children: History Wars in the Classroom, Sydney: UNSW Press, ch.3, pp.64-89.

Curthoys, A., 2008, 'WEH Stanner and the historians', in M. Hinkson and J. Beckett, (eds), An 
Appreciation of Difference: WEH Stanner and Aboriginal Australia, Aboriginal Studies Press, Canberra, pp. 233-250.

Gillen, P. and Ghosh, D. 2007, 'Race' in Colonialism and Modernity, UNSW Press, pp. 156-177.

Goodall, H. 1995, 'New South Wales', in A. McGrath (ed.) Contested Ground: Australian Aborigines under the British Crown, Allen \& Unwin, St Leonards, NSW, pp. 55-120.

Goodall, H. 2002, 'Too early or not soon enough? Reflections on 'sharing' histories as process not collection’, Australian Historical Studies, Vol. 33, No 118, pp. 7-24.

https://doi.org/10.1080/10314610208596176

Griffiths, B., Russell, L. \& Roberts, R. 2017, 'Friday essay: when did Australia's human history begin?', November 17, The Conversation, viewed 28 May 2018, $<\underline{\text { https://theconversation.com/friday-essay-when-did-australias-human-history-begin-87251>. }}$.

Korff, J. 2018, What you need to know about reconciliation, viewed 3 June 2018, $<\underline{\text { https://www.creativespirits.info/aboriginalculture/people/what-you-need-to-know-about- }}$ $\underline{\text { reconciliation }>\text {. }}$

Langton, M. 2013, Indigenous Exceptionalism and the Constiutional 'Race Power', Space, Place and Culture.

Manne, R. 2009, 'The History Wars', November, The Monthly, viewed 4 June 2018, $<$ https://www.themonthly.com.au/issue/2009/november/1270703045/robert-manne/comment>.

Marchetti, E. and Ransley, J. 2005, 'Unconscious Racism: Scrutinising Judicial Reasoning in 'Stolen Generation' Cases', Social and Legal Studies, Sage Publications, London, Vol. 14, No. 4, pp.533 - 552.

McGaw, B. 2014, 'Cross-curriculum priorities are options, not orders', The Canberra Times, 27 February, viewed 3 June 2018, <https://www.canberratimes.com.au/opinion/crosscurriculumpriorities-are-options-not-orders-20140226-33iae.html $>$.

Morris, B., 1992, 'Frontier colonialism as a Culture of Terror' in, Power, Knowledge and Aborigines, La Trobe University Press in association with the National Centre for Australian Studies, Monash University, Vic, pp. 72-87.

Native Title Act, 1993, (Cth.)

NSW Aboriginal Land Council 2017, Comparison of Land Rights and Native Title in NSW, viewed 31 May 2018, < http://alc.org.au/media/82940/170110\%20native $\% 20$ title $\% 20$ fact $\% 20$ sheet $\% 201 \% 20$ \%20comparison $\% 20$ of $\% 20$ land $\% 20$ rights $\% 20$ and $\% 20$ native $\% 20$ title $\% 20$ final.pdf $>$. 
Reconciliation Australia 2016, The State Of Reconciliation In Australia, viewed 24 May 2018, <http://www.reconciliation.org.au/wp-content/uploads/2017/11/State-of-ReconciliationReport_SUMMARY.pdf $>$.

Salter, P. and Maxwell, J. 2015, 'The inherent vulnerability of the Australian Curriculum's crosscurriculum priorities', Critical Studies in Education, Vol. 57, No. 3, pp. 296-312.

https://doi.org/10.1080/17508487.2015.1070363

Santayana, G. 2011, The Life of Reason: Introduction and Reason in Common Sense, MIT Press, Cambridge, Vol. 7, No. 1.

Stanner, W.E.H. 1969, 'The Great Australian Silence', in, The 1968 Boyer Lectures: After The Dreaming, Sydney, ABC Enterprises, pp. 18-29.

Stephenson, P. 2003, 'Beyond Black and White: Aborigines, Asian-Australians and The National Imaginary' $\mathrm{PhD}$ thesis, The University of Melbourne, Vic.

Super Nomads: 50,000 To 30,000 Years Ago, 2015, documentary episode 1 of 4, First Footprints, ABC.

Taylor, T. 2016, 'Australia's 'history wars' reignite', 31 March, The Conversation, viewed 6 June 2018, < https://theconversation.com/australias-history-wars-reignite-57065>. 